\title{
Integrated weed management in direct seeded rice in Trans Indo-Gangetic plains of India- A review
}

\begin{abstract}
Ajay Singh*
Department of Agronomy, CCS Haryana Agricultural University, Hisar-125004 (Haryana), India D. P. Nandal

Department of Agronomy, CCS Haryana Agricultural University, Hisar-125004 (Haryana), India S. S. Punia

Department of Agronomy, CCS Haryana Agricultural University, Hisar-125004 (Haryana), India Priti Malik

Department of Agronomy, CCS Haryana Agricultural University, Hisar-125004 (Haryana), India

*Corresponding author. E-mail: ajayyadavhau@gmail.com

Abstract

In the Indo-Gangetic Plains (IGP) of India, rice (Oryza sativa L.) is taken by conventional tilled puddled transplanted (CT-PTR) method. CT-PTR requires a lot of water (2000-2500 $\mathrm{mm}$ ) which comes mainly from groundwater. Due to declining water table and changing climate, the sustainability of CT-PTR rice is under immense pressure. The alternative to CT-PTR could be direct seeded rice (DSR) which requires less water, labor, initial cost and energy than CT-PTR. But direct seeded rice is heavily infested with weeds which cause severe loss to the grain yield. Thus, the success of aerobic rice depends on effective and timely weed control. As a single weed control method may not be successful on a long term basis, weed problem in direct seeded rice needs to be solved by integrated approach. Integrating cultural, mechanical and chemical methods along with highly competitive cultivars with effective allelopathic properties, effective weed management on long term sustainable basis can be achieved.
\end{abstract}

Keywords: Aerobic rice, Allelopathy, Competitive Cultivars, Direct seeded rice, Puddled transplanted rice

\section{INTRODUCTION}

Rice (Oryza sativa L.) is the most important cereal crop of India and feeds the belly of more than 800 million Indians. It has a share of $41.39 \%$ in total food grain produced and $55 \%$ of cereals produced in the country, contributing $20-25 \%$ to Agricultural GDP (Anonymous, 2016). In India, rice is grown on nearly $43.49 \mathrm{~m}$ ha with total production of $104.4 \mathrm{~m} \mathrm{t}$ and productivity of $2400 \mathrm{~kg} / \mathrm{ha}$ (Anonymous, 2016).

In India, the IGP cover about $20 \%$ of the total geographical area (329 Mha) and about $27 \%$ of the net cultivated area, and produce about $50 \%$ of the total food consumed in the country (Dhillon et al., 2010). It is spread across five Indian states, Punjab, Haryana, Utter Pradesh, Bihar and West Bengal. Trans Indo Gangetic Plain (TIGP) in India is spread across Punjab and Haryana. TIGP constitute a highly productive RW zone contributing about $69 \%$ of the total food output i-n the country (about $84 \%$ wheat and $54 \%$ rice) and this region is called the "food bowl of India." This region has played a vital role in sustaining the food security of India by contributing about $40 \%$ of wheat and $30 \%$ of rice to the central stock of India every year dur-

\section{Article Info}

DOI:10.31018/jans.v10i2.1679 Received: February 24, 2018

Revised: April 25, 2018

Accepted: May 18, 2018

\section{How to Cite}

Singh, A. et al. (2018).

Integrated weed management in direct seeded rice in Trans Indo-Gangetic plains of India- A review. Journal of Applied and Natural Science, 10(2): 779 - 790 
2013).

But repeated puddling destroys soil aggregates, thereby decreasing permeability in sub-surface layers and forming hard-pans (Aggarwal et al., 1995; Sharma and Datta, 1985; Sharma et al.,2003), all of these prove detrimental to succeeding crop usually wheat in IGP (Hobbs and Gupta, 2000).

Moreover, puddling requires additional water ( $200 \mathrm{~mm}$ ) which is becoming scarce day by day and labour which becoming costlier each day. So, with increasing cost of cultivation paddy production is become less profitable to the farmers. In India per capita water availability decreased by $72.3 \%$ between 1951 and 2005 (5831 $\mathrm{m}^{3}$ and $1611 \mathrm{~m}^{3}$ in 1951 and 2015 respectively) and is likely to decline by $77.8 \%$ by $2050\left(1292 \mathrm{~m}^{3}\right.$ in 2050). So scarcity of water, less availability of labour acts as driving force for direct seeding (Kumar and Ladha, 2011). All these above factors demand a major shift from conventionally tilledpuddle transplanted rice (CT-TPR) to direct seeding of rice (DSR).

Pandey and Velasco (2002) argued that transplanted is prevalent in areas where wages rates are low and water availability is enough whereas high wage rates and less availability of water favours adoption of direct seeded rice. So, aerobic rice could replace puddled transplanted rice. Direct seeded rice matures 7-11 days earlier than transplanted rice allowing timely sowing of next crop (Giri, 1998; Singh et al., 2006).

Other benefits of DSR include easier planting by direct seeded machine, improvement of soil structure, higher tolerance to water deficit, less emission of methane and often higher profit in areas with an assured water supply (Datta, 1986). Both Dry and Wet-DSR have the potential to reduce the water and labour use compared with CT-TPR. Tabbal et al. (2002) under on-farm trials in Philippines observed on an average $67-104 \mathrm{~mm}$ of saving in irrigation water in Wet-DSR compared with puddled-transplanted rice when irrigation application criteria was same for both establishment methods. Other than saving water, DSR reduced total labour requirement $11 \%-66 \%$ depending on season, location and type of DSR compared with CT-TPR (Kumar et al., 2009; Rashid et al., 2009). Labour requirements for crop establishment decreased by more than $75 \%$ with direct seeding compared with transplanting (Dawe, 2005; Pandey and Velasco, 2002).

But direct seeded rice are heavily infested with weeds, so success of DSR depends on effective weed management (Chauhan and Yadav 2013; Singh et al., 2006a; Rao et al., 2007; Singh et al., 2007). Many studies have reported the potential for DSR as a replacement for transplanted rice if weeds are controlled effectively (Singh et al., 2007). Aerobic systems are subjected to much higher weed pressure than CPTR (Rao et al., 2007 ) in which weeds are suppressed due to prevailing anaerobic environment in flooded conditions and by 25-30 days old transplanted seedlings which have an edge over germinating weed seedlings(Moody, 1983).

So managing weeds effectively is the major challenge in DSR, as failure to manage weeds results in very low or no yield (Singh et al., 2008; Moody and Mukhopadhyay, 1982). In DSR first 30-45 days after sowing is critical period and weeds must be managed effectively in this period otherwise there will be much loss in the yield. Maity and Mukherjee (2008) reported that uncontrolled weeds reduced the yield by $96 \%$ in dry-DSR and $61 \%$ in wet-DSR.

So the success of DSR depends largely on effective weed management especially the integrated approach. As a single method may not provide adequate control and for long term sustainability, integrated approach is the best option.

Weed flora of DSR: Direct seeded rice is infested by complex weed flora including various grasses, broadleaf and sedges. Singh et al. (2017) reported Echinochloa glabrescens, Leptochloa chinensis, Cyperus spp. Ammania baccifera, Eclipta alba as predominant weed species in direct seeded rice at Kaul (Kaithal) Haryana. Saha (2006) reported that DSR was mainly infested by sedges including Cyperus difformis (30.2\%), Fimbristylis miliacea (27\%) followed by BLW Ludwigia parviflora (17.5\%) Sphenochlea zeylancia (15.8\%) and grasses Echinochloa colona (9.5\%).

However, Mishra and Singh (2008) reported that direct seeded rice was infested mainly by BLW including Phyllanthus spp.(26.5\%), Commelina communis (17.8), Physlis minima (1.8\%), Alternanthera sessilis (5.9\%), Caesulia axillaris(1.2\%), grasses Echinochloa colona (31.8\%) and sedges Cyperus iria (9.9\%). So the composition and species of weed vary from region to region.

Losses caused by weeds: The productivity of crops to a greater extent depends upon efficient resource management. Among many factors responsible for low yield in Indian agriculture, problem of weed is one of the major factors causing losses in crop yield in general and under direct seeded rice in particular. Heavy weed infestation and poor weed management contribute to poor yield in aerobic rice (Bhurer et al., 2013).

Crop-weeds competition depends on a number of factors such as the weed species, type of rice culture, methods of planting and cultural practices. Rice crop suffers more if weeds compete for resources during initial crop growth period and competes for a longer period. This results in poor growth of rice plants which eventually leads to poor yield. Weeds heavily repress the growth of rice during initial $30-40$ days.

The slow initial seedling establishment and growth 
Singh A. et al. / J. Appl. \& Nat. Sci. 10 (2): 779 - 790 (2018)

Table 1. Different type of mulches, their suppressive ability on particular weeds and increase in yield.

\begin{tabular}{|c|c|c|c|c|c|}
\hline Type of mulch & $\begin{array}{l}\text { Rate } \\
\text { (t/ha) }\end{array}$ & Weeds & $\begin{array}{l}\text { Weed sup- } \\
\text { pression (\%) }\end{array}$ & $\begin{array}{l}\text { Increase in } \\
\text { yield (\%) }\end{array}$ & Reference \\
\hline Wheat mulch & 4 & Grass and BLW & 54 & 22 & (Singh et al ,. 2007) \\
\hline Plastic mulch & & Complex & $69-77$ & 45 & $\begin{array}{l}\text { (Mohtisham et al., } \\
\text { 2013) }\end{array}$ \\
\hline Paper mulch & & $\begin{array}{l}\text { Echinochloa spp., Schoe- } \\
\text { noplectus mucronatus }\end{array}$ & $61-97$ & & (Wentao et al .,2003) \\
\hline Maize mulch & 5 & Complex & $48-56$ & 32 & $\begin{array}{l}\text { (Mohtisham et al., } \\
\text { 2013) }\end{array}$ \\
\hline $\begin{array}{l}\text { Sugarcane trash } \\
\text { mulch }\end{array}$ & 5 & Complex & $26-32$ & 16 & $\begin{array}{l}\text { (Mohtisham et al., } \\
\text { 2013) }\end{array}$ \\
\hline Alfalfa & 1 & $\begin{array}{l}\text { E.phyllopogon, } \\
\text { choria vaginalis }\end{array}$ & $\sim 90$ & 81 & (Xuan et al., 2003) \\
\hline
\end{tabular}

Table 2. Common pre-emergence herbicides used in direct seeded rice in India.

\begin{tabular}{lllll}
\hline $\begin{array}{l}\text { S. } \\
\text { No. }\end{array}$ & $\begin{array}{l}\text { Name of the } \\
\text { herbicide }\end{array}$ & $\begin{array}{l}\text { Dose } \\
\text { ha) }\end{array}$ & $\begin{array}{l}\text { Time of } \\
\text { application }\end{array}$ & References \\
1. & Pendimethalin & $0.75-1.0$ & PRE & (Singh et al.,2016;Singh et al., 2017;Gopal et al., 2010) \\
2. & Oxadiargyl & $0.09-0.10$ & PRE & (Singh et al., 2016; Singh et al.,2017) \\
3. & Pyrazosulfron & $0.015-0.020$ & PRE & (Kaur and Singh, 2015) \\
4. & Butachlor & $1.0-1.50$ & PRE & (Singh et al., 2016, Kaur and Singh, 2015) \\
5. & Penoxsulam & 0.030 & PRE & (Walia et al., 2012) \\
6. & Pretilachlor & $0.40-0.75$ & PRE & (Walia et al., 2012) \\
7. & Thiobencarb & 1.25 & PRE & (Walia et al., 2012) \\
8. & Flufenacet & 0.08 & PRE & (Walia et al., 2012) \\
9. & Anilofos & 0.375 & PRE & (Kaur and Singh, 2015) \\
\hline
\end{tabular}

of young seedlings are more sensitive to weed competition in direct seeded rice and yield loss up to $57.6 \%$ due to uncontrolled weed growth has been reported by Singh (2017).

Aerobic conditions along with alternate wetting and drying favours the germination and growth of weeds in direct seeding which causes yield loss upto 50-91\% (Bhurer et al ., 2013; Singh and Chinnusamy, 2006).

Bhurer et al. (2013) claimed that weeds are supposed to be the foremost factor that causes heavy yield reduction varying from 40 to $76 \%$ in broadcast seeded, $20 \%$ in drill seeded and 11 to $20 \%$ in transplanting in puddled fields. Malik et al. (2002) reported that uncontrolled weeds in rice can cause grain yield loss upto $89.9 \%$ as compared to weed free.

Yield loss of rice due to uncontrolled weeds was $96 \%$ in dry DSR, $61 \%$ in wet DSR and $40 \%$ in the machinery-transplanted crop (Kim and Pyon, 1998). Choubey et al. (2001) also reported that weeds are the major biotic constraints to crop production and in direct seeded rice they reduce the yield by 40 to $100 \%$. Yield losses without proper weed management can reach to $70-100 \%$ in dry seeding versus only 10-35 \% for machinetransplanted rice (Lee et al., 2002). The loss of yield in unweeded direct-seeded rice has been estimated to be $45-66 \%$, whereas it was $13 \%$ in transplanted rice (Thakur, 2006).

Reported yield losses from weeds in DSR ranged from 20 to $88 \%$ (Rao and Moody, 1994). Yield reduction upto 50 to $60 \%$ and sometimes complete failure of the rice crop due to heavy infesta- tion of weeds under direct seeded upland conditions has been reported by various researchers (Singh, 1988; Singh et al., 2002; Raju and Gangwar, 2004; Singh et al., 2005b; Singh et al., 2017).

Methods of weed control: Integrated weed management (IWM) is desirable for effective and sustainable weed control in Dry-DSR (Rao and Nagamani, 2007; Rao et al., 2007). Tools available for IWM can be categorized broadly into (a) cultural, (b) chemical, (c) mechanical, and (d) allelopathic approach for weed control.

\section{Cultural methods of weed control}

Land levelling: Proper land preparation helps in reducing weed infestation by providing a weed free seed bed at the time of sowing. To achieve uniform crop stand the field should be levelled before crop sowing.

In Indo-Gangetic plains, a deviation of $8-15 \mathrm{~cm}$ in field level is observed due to traditional levelling. This results in poor crop establishment of rice due to unequal distribution of water in soil profile and inundation of newly germinating seedlings (Gopal et al., 2010). Laser land levelling ensures better crop establishment (Jat et al., 2009), precise water control and increased herbicide use efficiency (Chauhan, 2012).

Time of sowing, seed rate and spacing: In northern India, rice is grown during the kharif season before onset of monsoon. To optimize the use of monsoon rain, the optimum time for sowing DSR is about 10-15 days before onset of monsoon (Gopal et al., 2010; Kamboj et al., 2012; Kumar and Ladha 2011; Gopal et al., 2010). A seed rate 
of 20-25 kg/ha has been found optimum for basmati rice cultivars with a spacing of $20 \mathrm{~cm}$ (Yadav et al., 2007).

High seed rates results in excessive vegetative growth thereby utilizing most of the resources before anthesis and less accumulation of dry matter after anthesis (Wells and Faw, 1978). This results in lower $\mathrm{N}$ content in foliage (Dingkuhn et al., 1990 ) and results in sterility of spikelet and less grains per panicle (Kabir et al., 2008).

Moreover, dense plant populations at high seed rates can create favourable conditions for diseases, e.g., sheath blight (Guzman and Nieto 1992; Mithrasena and Adikari 1986) and insects (e.g., brown plant hoppers) and make plants more prone to lodging due to weak stem (Islam et al., 2008).

Lower seed rate can be used for high-tillering varieties and a little higher seed rate for mediumtillering varieties (Soo et al., 1989).

Seeding depth is another important aspect which must be kept in mind. In DSR, seeding should be done with precision planters having depth control wheels. Seed depth plays an important role in germination and seedling emergence in DSR. Semi-dwarf varieties are highly sensitive to seeding depth due to their shorter mesocotyl as compared to conventional tall varieties (Blanche et al., 2009).

The germination of seedling is decreased when seed is placed too deep or at shallow depth. When the seed is placed too deep, there are chances that the shoot tip will be damaged due to weak coleoptile, while if seeds are placed near surface, germination is affected by rapid drying of soil surface and high temperature near soil surface due to incoming solar radiation (Gopal et al., 2010). Maximum depth upto which rice seeds can be drilled is $2.5 \mathrm{~cm}$, deeper than $2.5 \mathrm{~cm}$ results in uneven crop establishment (Kamboj et al., 2012).

Stale seed bed technique: Stale seedbed technique can be used to decrease weed seed bank from soil where a particular cropping system is followed year after year. This could be very useful in IGP where rice-wheat is the major cropping system. It depletes $5-10 \%$ of weed seeds present in soil.

In stale seedbed after tillage, light irrigation is applied to facilitate proper germination and emergence of weed seedlings. Single irrigation is given 15 days before sowing to maximize weed germination and after that soil moisture is maintained at optimum level. A non-selective herbicide (glyphosate or paraquat) or mechanical method is used to kill emerged weeds (Anonymous, 2017).

Stale seedbed can be very effective when weed species have low dormancy, are placed near soil surface (in Zero-tillage) and favourable environmental conditions (light, optimum temperature) are present (Chauhan, 2012).
Singh et al. (2009b) reported that using stale seedbed technique in direct seeded rice, weed density can be reduced by $53 \%$ over control. Chauhan and Johnson (2010) observed better weed control when stale seedbed with paraquat is used with zero-till because weed seeds placed deeper than $1 \mathrm{~cm}$ do not emerges.

Combined use of stale seedbed along with pendimethalin gave effective control of weeds in DSR in in large-scale farmer participatory trials in India (Singh et al., 2005c).

Mulching: Applying mulch on soil is another of controlling weeds in direct seeded rice. Besides conserving moisture mulch suppresses weeds, prevents soil erosion, add organic matter to soil, improve soil health and decrease fluctuations in diurnal temperature (Qin et al., 2010).

Mulches are thought to supress weeds by physical obstruction to germinating weed seeds, block incoming sunlight and by release of certain allelochemicals. Kumar et al. (2013) reported that problematic weeds of DSR such as Echinochloa crusgalli, E. colona, Dactyloctenium aegyptium and Eclipta alba were sensitive to wheat straw used as mulch.

Batish et al. (2007) claimed that when residue of Tagetes minuta L. was used as mulch it suppresses growth of $E$. crus-galli and $C$. rotundus. Hong et al. (2004) reported through allelopathy certain plants like with Clerodendrum trichotomum Thunb., Datura stramonium L., Desmodium triflorum (L.) DC. and Melia azedarach L. were found to supress weeds in rice by $70-90 \%$.

Singh et al. (2007) studied the effect of weed suppression ability of weeds with wheat straw $4 \mathrm{t} / \mathrm{ha}$ spread uniformly at SVBPU and T and found that during early stage (30 DAS) mulch resulted into highest reduction in total weed density (54\%) which may be due to inhibitory effect of allelochemicals released by wheat on weed seed germination. Also wheat straw results in better weed control and gain in grain yield of rice. Wheat straw reduced grasses and BLW by $46 \%$ and $71 \%$ respectively, and increases grain yield of rice by $22 \%$. This result in higher economic returns compared to control (Singh et al., 2007).

Hamdi et al. (2001) reported that suppressive effect of wheat straw on ryegrass may be through release of leachates and organic molecules may be involved.

The straw generated in wheat crop can be best utilised by spreading over the surface. This will also solve the problem of straw management as burning straw in the IGP is another serious issue. Encouraging results with the use of straw mulch from previous crop have been reported by Talukder et al. (2006). Straw mulch from previous crop along with post emergence herbicides could be promising strategy to control weeds in direct seeded rice. 
Table 3. Common post-emergence herbicides used in direct seeded rice in India

\begin{tabular}{|c|c|c|c|c|}
\hline $\begin{array}{l}\text { SI. } \\
\text { No }\end{array}$ & Name of the herbicide & Dose (kg/ha) & $\begin{array}{l}\text { Time of appli- } \\
\text { cation (DAS) }\end{array}$ & Reference \\
\hline 1. & Bispyribac-sodium & 0.025 & $25-30$ & $\begin{array}{l}\text { (Kaur and Singh, 2015; Walia et al., } \\
2008 \text { ) }\end{array}$ \\
\hline 2. & Fenoxaprop-p-ethyl & $0.06-0.075$ & $25-30$ & (Upasani and Barla, 2014) \\
\hline 3. & Ethoxysulfuron & $0.015-0.0175$ & $25-30$ & (Upasani and Barla, 2014) \\
\hline 4. & $\begin{array}{l}\text { Chlorimuron-ethyl+ met- } \\
\text { sulfuron-methyl }\end{array}$ & $0.002-0.004$ & $25-30$ & (Singh et al., 2010; Singh et al., 2017) \\
\hline 5. & Acifluorfer & 0.60 & $20-30$ & (Sankula et al.,1997) \\
\hline 6. & $2,4-D$ & 1.0 & 30 & (Angiras and Attri, 2002) \\
\hline
\end{tabular}

Weed competitive cultivar: Weed-competitive cultivars can be a low cost but promising strategy to get higher yield and economic returns (Andrew et al., 2015). Varieties having good mechanical strength of coleoptile for rapid germination and higher seedling vigour to compete weeds are best suited for direct seeding (Jannink et al., 2000; Zhao et al., 2006).

Ranasinghe (1995) conducted field experiments to identify morphological traits which provide competitive ability to rice plants against weeds. He found that rice-barnyard grass competition varies significantly with the morphology of rice cultivar. Cultivar which attains more plant height, leaf area and higher dry matter accumulation during seedling stage and more plant height and leaf area at the time of maturity offers more competition to the weeds.

Better developed roots, high leaf area index and tillering capacity were the characters associated with weed suppressive rice cultivars (Fofana and Rauber, 2000). Perera et al. (1992) observed that under high crop-weed competition the root growth, root biomass and nutrient uptake is reduced in rice cultivars.

Gealy and Moldenhauer (2012) reported that weed suppressive rice cultivars have twice root biomass than those of non-suppressive types. Due to higher root biomass and root proliferation, weed suppressive cultivars competed better for resources with weeds and reduced weed loss by $44 \%$ and weed prevalence by $30 \%$ as compared to non-suppressive cultivars (Gealy and Moldenhauer, 2012).

Therefore varieties suitable for direct seeded require characters like efficient root system for better anchorage and to draw moisture from deeper soil layers during peak evaporation demands (Clark et al., 2000; Pantuwan et al., 2002) and a wider window of sowing time. In Punjab and Haryana region, variety PUSA-1121, PR-115, PAU201 etc. are suited for direct seeding.

Crop rotation: Crop rotation is very useful in controlling weeds. There are certain crop associated weeds which can be controlled simply by changing cropping system. Changing cropping system shifts the weed flora in which some weeds disappear and new weeds emerges. Singh et al. (2008) studied change in composition of weeds, weed density and weed dry weight when rice-wheat cropping sequence is changed. They found that minimum weed density was recorded in ricewheat-green gram sequence followed by ricewheat, rice-chickpea and rice-pea sequence.

Changing rice-wheat rotation also helps in identification of weedy rice. By rotating rice with soybean, mungbean, Kharif maize or cotton etc., weedy rice can be controlled because other herbicides and cultural practices can be used which cannot be used in rice (Singh et al., 2013). Chhokar et al. (2008) reported that introduction of potato and pea in between rice and wheat can also improve weed control without herbicide applications.

Brown manuring: Brown manuring with sesbania in direct seeded rice can be a good option to control weeds, improve soil health and get higher yield. Seeds of sesbania $20 \mathrm{~kg} / \mathrm{ha}$ can be drilled in between the rows of direct seeded rice 3 days after sowing of rice and sprayed with 2,4-D ethyl ester $0.50 \mathrm{~kg} / \mathrm{ha}$ to produce sesbania brown manure.

Nawaz et al. (2017) evaluated five different ricewheat cropping systems and found that brown manuring in direct seeded rice with sesbania decreased weed density by $41-56 \%$ and weed bio mass by $62-75 \%$ than sole direct seeded rice.

Seed priming: Seed priming are primarily aimed at hydration of seeds for a specific period of time to complete pre-germinative metabolic process but emergence of radicle is avoided. Priming may be done with water (hydro-priming), salt solution$\mathrm{NaCl}$ (halo priming) or use of moist sand (sand matric priming). Priming increases germination percentage, gave uniform germination, improves resistance towards water and temperature stress, and increases the yield.

Increased vigour in direct seeded Aeron 1 by different priming treatments was observed by Juraimi et al. (2012). They reported primed seeds produced vigorous seedling with $50 \%$ higher vigour index than unprimed seeds

Anwar et al. (2012) claimed that primed seeds reduce weed dry weight by 22 to $27 \%$ mainly due to good crop establishment with vigorous seedlings and quick canopy development. They also found that primed rice seeds produce $0.4 \mathrm{t} / \mathrm{ha}$ more yield over control. 
Mechanical and manual methods of weed control: Controlling weeds through any physical activity that inhibits growth of weeds is mechanical control.

Mowing: Mowing is removing or cutting shoot of weeds by using sickle or mower. It is successful for controlling annual weeds while less practiced in case of perennial weeds because perennial weeds have stored food in below ground parts (rhizomes, stolones etc.) and come in several flushes. Mowing must be done before flowering or seed setting to prevent dispersal of seeds. Weed thus obtained should be buried deep or burnt to remove viability of weed seeds (Matloob et al., 2015).

Mechanical weeder: The mechanical methods control weeds and gave yield at par with chemical control provided they are done properly. Mechanical weeding is not practiced in IGP due to labour and economic constraint.

Muthukrishnan and Purushothaman (1992) reported that HW twice at 25 and 45 DAS effectively controlled the weeds, resulting in higher grain yield over un-weeded check. Mehta et al. (1993) observed that HW twice, at 20 and 30 DAS, produced rice grain yield of $3.2 \mathrm{t} / \mathrm{ha}$ at par with weed free ( $\mathrm{HW}$ four times) yielding $3.3 \mathrm{t} / \mathrm{ha}$ and higher than one HW ( $2.5 \mathrm{t} / \mathrm{ha}$ ) and weedy (1.0 t/ha).

Singh et al. (2003) reported from Pantnagar, India that pendimethalin at $1.0 \mathrm{~kg} / \mathrm{ha}$ along with farm waste as mulch (7.5 t/ha) supplemented with one $\mathrm{HW}$ at 45 DAS decreased weed count, weed biomass with highest weed control efficiency $(91.3 \%)$ which was comparable with HW thrice at 30,60 and 90 DAS (farmers' practice).

Manual weeding can be implemented only when weeds have reached a sufficient size to be pulled and it has an inherent opportunity cost. Manual weeding is therefore often practiced late as evident by yield loss comparisons of the effects of manual weeding at 21-30 DAS with those from the use of early post-emergence herbicides (Singh et al., 2005a).

Labour scarcity, high labour cost, poor weather conditions and the presence of perennial weeds that breaks down on pulling may all lead to lower efficiency of hand weeding.

Mechanical weeding using simple implements remains a practical and economic method for many small and marginal farmers of Asia and Africa. Mechanical weeding is almost universally practised on row-seeded rice since inter row cultivation with either hand tools or animal traction equipment reduces time in weeding and minimizes crop damage.

Sarma and Gogoi (1996) reported that in rain-fed upland rice in India, a manually operated peg-type dry-land weeder which is operated manually (with a straight-line peg arrangement) has shown excellent performance across a wide range of soil types<smiles>CC(=O)/C=C/C1=C(C)CC(O)CC1(C)C</smiles>

Fig. 1. Allelochemicals isolated from rice (Olofsdotter et al., 1995; Chung et al., 1997; Dilday et al., 1998; Hassan et al., 1998)

with varying soil moisture levels and weed intensity providing a labour saving of $\sim 57 \%$ compared with hand weeding ( 127 person-days/ha).

Chemical method of weed control: Labour unavailability, increasing labour costs, and the pressing need to raise yield and maintain profit on a progressively limited land base have been the major drivers for farmers to seek alternatives to manual weeding. Herbicides are one such alternative. Effective weed management practices are an important pre-requisite in DSR culture, with herbicide application seemingly indispensable (Azmi et al., 2005). The trend for an increase in herbicide use has been reinforced by the spread of DSR (Naylor, 1994).

Pre-emergence herbicides: Different preemergence herbicides are used for controlling weeds in direct seeded rice in India (Table 2.). Among them, pendimethalin $1.0 \mathrm{~kg} / \mathrm{ha}$, oxadiargyl $(0.10 \mathrm{~kg} / \mathrm{ha})$ and pyrazosulfron $(0.02 \mathrm{~kg} / \mathrm{ha})$ were found to give effective weed control (Gupta et al., 2006a; Rao and Nagamani, 2007; Singh et al., 2009; Gopal et al., 2010; Singh et al., 2017).

Pendimethalin is a selective herbicide effective against most annual grasses and several annual broad leaves weeds. It belongs to chemical class of dinitroaniline. It acts via inhibition of microtubule formation, disrupting cell division and causing microfibril disorientation, so it's a germination inhibitor. Pendimethalin controls Echinochloa spp. more effectively as compared to Cyperus spp. Pendimethalin at $0.90 \mathrm{~kg} / \mathrm{ha}$ provided excellent control of weedy rice and best control of grassy weeds (Joseph et al., 1990), whereas Malik et al. (2002) reported that pendimethalin was effective only against Echinochloa spp., Cyperus iria and Commelina banghalensis. It shows poor efficacy against Leptochloa chinensis, another predominant weed in direct seeded rice (Singh et al., 2017).

Singh et al. (2016) evaluated three preemergence herbicides pendimethalin $1.0 \mathrm{~kg} / \mathrm{ha}$, butachlor $1.0 \mathrm{~kg} / \mathrm{ha}$ and oxadiargyl $0.09 \mathrm{~kg} / \mathrm{ha}$ and found weed density after application of these herbicides were $10-13,15$ and $16-23$ plants $/ \mathrm{m}^{2}$ respectively compared to 51 plants $/ \mathrm{m}^{2}$ in weedy check at Taraori location. At Madhuban location, highest grain yield of direct seeded rice (3.43 t/ha) was obtained with pendimethalin $1.0 \mathrm{~kg} / \mathrm{ha}$ PRE fb 
bispyribac-sodium $0.025 \mathrm{~kg} / \mathrm{ha}$ and azimsulfuron $0.0225 \mathrm{~kg} / \mathrm{ha}$ POST which was comparable under weed free $(3.5 \mathrm{t} / \mathrm{ha})$.

Kaur and Singh (2015) evaluated seven preemergence (pendimethalin $0.75 \mathrm{~g} / \mathrm{ha}$, Butachlor $1.50 \mathrm{~kg} / \mathrm{ha}$, Thiobencarb $1.50 \mathrm{~kg} / \mathrm{ha}$, Anilofos $0.375 \mathrm{~kg} / \mathrm{ha}$, Pretilachlor $0.75 \mathrm{~kg} / \mathrm{ha}$, Oxadiargyl $0.09 \mathrm{~kg} / \mathrm{ha}$, Pyrazosulfuron-ethyl $0.015 \mathrm{~kg} / \mathrm{ha}$ ) herbicides for their efficacy against weeds in DSR. Application of pendimethalin $0.75 \mathrm{~kg} / \mathrm{ha}$ PRE produce significantly lower weed density of Echinochloa spp. at 30 DAS than all other pre emergence herbicides. Similarly, the density of Cyperus spp. was similar in all pre-emergence herbicides. However, the weed dry matter of Cyperus spp. in Pyrazosulfuron-ethyl $0.015 \mathrm{~kg} / \mathrm{ha}$ treated plots was at par with unweeded at 30 DAS.

Post-emergence herbicides: In direct seeded rice, more than one flush of weeds occurs during crop duration. Pre emergence herbicides gave effective control during early stage of crop growth and post emergence herbicides during the second flush of weeds. If weeds were not controlled properly, they can cause significant qualitative and quantitative loss in grain yield. A single herbicide cannot give effective weed control throughout crop growth period so sequential herbicide application is done. A list of common post emergence herbicides used in direct seeded rice in India is given in Table 3 .

Walia et al. (2008) claimed that application of bispyribac-Na @ $0.025 \mathrm{~kg} / \mathrm{ha}$ controlled all type of weeds in direct seeded rice and was found very effective against problematic weeds of DSR i.e. Echinochloa spp. and Cyperus spp. Also, Kaur and Singh (2015) reported that application of bispyribac-Na $0.025 \mathrm{~kg} / \mathrm{ha}$ POST after six preemergence herbicides (butachlor, thiobencarb, anilofos, pretilachlor, oxadiargyl and pyrazosulfuron-ethyl) produced lower weed density than these six pre-emergence herbicides applied alone.

Singh et al. (2017) at Kaul, Kaithal (Haryana) claimed that Leptochloa chinensis can be controlled effectively by fenoxaprop-p-ethyl $0.067 \mathrm{~kg} /$ ha having weed control efficiency (WCE) of $92 \%$ than bispyribac-Na $0.025 \mathrm{~kg} / \mathrm{ha}$ with WCE of $38 \%$ in direct seeded rice (DSR). Singh et al. (2004) at Pantnagar also reported good control of $L$. chinensis by fenoxaprop-p-ethyl $0.056 \mathrm{~kg} / \mathrm{ha}$ while its efficacy against Echinochloa spp. and Cyperus spp. was poor than bispyribac-Na with WCE of 40 $\%$. Singh et al. (2010) evaluated azimsulfuron $0.025-0.030 \mathrm{~kg} / \mathrm{ha}$ at 25 DAS alone and tank mixed with chlorimuron-ethyl+ metsulfuron-methyl $0.004 \mathrm{~kg} / \mathrm{ha}$ and reported that tank mixing of chlorimuron-ethyl+ metsulfuron-methyl $0.004 \mathrm{~kg} / \mathrm{ha}$ does not improves the efficacy of azimsulfuron $0.025-0.030 \mathrm{~kg} / \mathrm{ha}$ against grasses weeds. Azimsulfuron $0.025-0.030 \mathrm{~kg} / \mathrm{ha}$ alone at 25 DAS gave effective control of BLW (Broad leaf weeds) and sedges especially Cyperus rotundus but poor control of grasses.

Mishra and Singh (2008) evaluated two pre emergence herbicides i.e., pendimethalin $1.0 \mathrm{~kg} / \mathrm{ha}$ and pretilachlor $0.75 \mathrm{~kg} / \mathrm{ha}$ followed by $1 \mathrm{HW}$ at 30 DAS or 2, 4-D (0.05 kg/ha) + fenoxaprop $(0.07 \mathrm{~kg} /$ ha) and reported that these treatments being at par were effective against weeds and gave significantly higher grain yield (3.07, 3.25, 3.23 and 3.14 $\mathrm{t} / \mathrm{ha}$, respectively) and benefits ( $\mathrm{B}: \mathrm{C}$ ratio of 1.75 , $1.75,1.86$ and 1.71 , respectively) than weedy check (1.36 t/ha and 0.95).

Singh et al. (2006) studied efficacy of herbicides in direct seeded rice cultivated in FIRBS (furrow irrigated raised bed planting system) and reported that application of fenoxaprop $0.050 \mathrm{~kg} / \mathrm{ha}+$ ethoxysulfuron $0.018 \mathrm{~kg} / \mathrm{ha}$ at $21 \mathrm{DAS}$ and pendimethalin $1.0 \mathrm{~kg} / \mathrm{ha}$ PRE $\mathrm{fb}$ chlorimuron-ethyl+ metsulfuron-methyl $0.004 \mathrm{~kg} / \mathrm{ha}$ at $21 \mathrm{DAS}$ were effective against mixed weed flora (WCE of 90 and $84 \%$, respectively) and economical also (Net income of 115 and 97 US \$, respectively). Mahajan et al. (2009) reported that application of bispyribac-Na $0.025 \mathrm{~kg} / \mathrm{ha}$ and penoxsulam $0.025 \mathrm{~kg} / \mathrm{ha}$ effectively controlled all the weeds in aerobic direct seeded rice (ADSR) with WCE of 85 and $67 \%$, respectively and grain yield were similar with conventional puddled transplanted rice (CPTR) (25.69 and 20.76 q/ha under ADSR and 30.02 and 28.58 q/ha under CPTR).

Mahajan and Timisina (2011) claimed that application of pendimethalin $1.0 \mathrm{~kg} / \mathrm{ha}$ PRE fb bispyribac-Na $0.030 \mathrm{~kg} / \mathrm{ha} 18 \mathrm{DAS}$ or pendimethalin 1.0 $\mathrm{kg} / \mathrm{ha}$ PRE fb bispyribac-Na $0.030 \mathrm{~kg} / \mathrm{ha} 18 \mathrm{DAS}+$ HW 45 DAS gave better weed control (WCE of 81 and $91 \%$, respectively compared to pendimethalin $1.0 \mathrm{~kg} / \mathrm{ha}$ PRE $\mathrm{fb}+\mathrm{HW} 45 \mathrm{DAS})$, higher grain yield (5.32 and $6.11 \mathrm{t} / \mathrm{ha}$, respectively), higher water productivity and profitability in direct seeded rice.

Walia et al. (2008) reported that application of pendimethalin $0.75 \mathrm{~kg} / \mathrm{ha}$ PRE followed by bispyribac-Na $0.25 \mathrm{~kg} / \mathrm{ha}$ or azimsulfuron $0.020 \mathrm{~kg} / \mathrm{ha}$ or 2,4-D $0.50 \mathrm{~kg} / \mathrm{ha}$ at 30 DAS resulted in better weed control (WCE of 87,84 and $78 \%$, respectively) and higher grain yield of rice (5618, 4747 and $4675 \mathrm{~kg} / \mathrm{ha}$, respectively). Application of pendimethalin $0.75 \mathrm{~kg} / \mathrm{ha}$ PRE fb bispyribac-Na $0.025 \mathrm{~kg} / \mathrm{ha}$ resulted in $372 \%$ increase in grain yield as compared to unweeded control $(1191 \mathrm{~kg} /$ ha). Application of pendimethalin provided effective control of non-predominant paddy weeds, whereas bispyribac-Na controlled typical predominant paddy weeds including Echinochloa colona and all Cyperus spp.

Singh et al. (2017) reported that pendimethalin 1.0 $\mathrm{kg} / \mathrm{ha} \mathrm{fb}$ bispyribac-Na and chlorimuron-ethyl+ metsulfuron-methyl $0.004 \mathrm{~kg} / \mathrm{ha}$ gave effective weed control (WCE of $75.4 \%$ ) with higher grain yield and profitability at par with weed free (3.97 
and $4.12 \mathrm{t} / \mathrm{ha}$ and 2.37 and 2.01 , respectively).

Allelopathy: Recent studies showed that rice plants and weeds also compete through allelopathy. Olofsdotter (2001) studied allelopathic potential of 111 rice cultivars on weeds in Philippine's and reported that dry weight of weeds reduced upto $34 \%$ after 8 weeks of seeding. The reduction in weeds dry weight is due to allelochemicals released by these rice cultivars (Olofsdotter et al., 2002). Kato-Noguchi et al. (2011) identified 3hydroxy- $\beta$-ionone and 9-hydroxy-4-megastigmen3-one (Fig. 1) as main allelochemicals in Kartikshail and BR 17, two high yielding rice cultivars of Bangladesh.

Allelopathic potential of many rice cultivars like BR17 against Echinochloa crus-galli and E. colonum had already been reported in various studies (Farooq et al., 2008; Farooq et al., 2011; Jabran and Farooq, 2013). -----Several rice cultivars through release of allelochemical had been found to suppress predominant weeds of rice, such as E. crus-galli (Jensen et al., 2001; Seal and Pratley, 2010), Cyperus difformis (Seal and Pratley, 2010), Sagittaria montevidensis (Seal and Pratley, 2010; Seal et al., 2004).

Seal and Pratley (2010) evaluated the allelopathic multi-weed suppression of 27 different rice cultivars against five major aquatic weeds of Australia and found that cultivar Amaroo inhibited Alismataceae weeds by an average of $97 \%$, whereas Echinochloa crus-galli was inhibited by $72 \%$. A non allelopathic cultivar, Langi stimulated root growth of $E$. crus-galli by almost $20 \%$.

In India not much work is done to exploit the rice's allelopathic property for weed control in direct seeded rice. Cultivars with improved allelopathic potential can be developed which compete better with weeds and lowers the dependence on herbicides. So, there is wide scope to identify, develop and exploit cultivars with higher allelopathic potential in proper cropping systems.

\section{Conclusion}

Weeds are the major biotic factors which hinder the growth and yield of direct seeded rice. Controlling weeds is pivotal for getting good grain yield of rice. Not a single weed control method is ecological viable and sustainable both ecologically as well as economically. Therefore, integrating different weed control methods on the basis of climatic conditions, edaphic factors, weed flora present and cultivars, effective weed management on a long term sustainable basis can be achieved. New weed control approach like allelopathy can be used along with other weed control methods to further reduce the losses caused by the weeds in direct seeded rice.

\section{REFERENCES}

Aggarwal, G.C., Sindhu, A.S., Sekhlon, N.K., Sandhu, K.S. and Sur, H.S. (1995). Puddling and N manage- ment effects on crop response in rice-wheat cropping system. Soil and Till. Rese. 36:129-139.

Andrew, K. S., Storkey, J. and Sparkes, D. L. (2015). A review of the potential for competitive cereal cultivars as a tool in integrated weed management. Weed Rese. 55: 239-248.

Angiras, N. N. and Rana, S. S. (1998). Butachlor safener combinations for weed control in direct-seeded puddled rice. Inter. Rice Rese. Notes. 23, 46.

Anonymous ( 2016). Indiastat base. Retreived from https://www.india.stat.com

Anonymous (2017). International Rice Research Institute, Rice Knowledge Book. Los Banos, Philippines. Accessed on 13.10.2017. url: http:// www.knowledgebank.irri.org/step-by-step-production/ growth/weed-management/stale-seedbed-technique.

Anwar, M. P., Juraimi, A. S., Puteh, A., Selamat, A., Rahman, M. M. and Samedani, M. (2012). Seed priming influences weed competitiveness and productivity of aerobic rice. Acta Agricul. Scand. 62:499-509.

Azmi, M., Chin, D. V., Vongsaroj, P. and Johnson, D. E. (2005). Emerging issues in weed management of direct-seeded rice in Malaysia, Vietnam, and Thailand. In "Rice Is Life: Scientific Perspectives for the 21st Century" (K. Toriyama, K. L. Heong, and B. Hardy, Eds.), pp. 196 198. International Rice Research Institute, Los Baños, Philippines, and Japan International Research Center for Agricultural Sciences, Tsukuba, Japan.

Batish, D. R., Arora, K., Singh, H. P., Kohli, R. K. (2007). Potential utilization of dried powder of Tagetes minutaas a natural herbicide for managing rice weeds. Crop Prot. 26: 566-571.

Bhurer, K.P., Yadav, D.N., Ladha, J.K., Thapa, R.B. and Pandey, K.R. (2013). Efficacy of various herbicides to control weeds in dry direct seeded rice (Oryza sativa L.). Global Journal of biology, agriculture and health sciences. 2(4):205-212.

Blanche, B., Harrell, D. and Saichuk, J. (2009). General Agronomic Guidelines. In "Louisiana rice production handbook 2009" (J. Saichuk, ed.), pp 3-15, Pub. 2321 (3M) 6/09 Rev.

Chauhan, B. S. and Johnson, D. E. (2010). The role of seed ecology in improving weed management strategies in the tropics. Advan. in Agron. 105: 221-262.

Chauhan, B. S. and Yadav, A. (2013). Weed management approaches for direct seeded rice in India: a review. Ind. J. Weed Sci. 45 (1):1-6.

Chauhan, B.S. (2012). Weed ecology and weed management strategies for dry-seeded rice in Asia. Weed Technol. 26:1-13.

Chhokar, R.S., Sharma, R.K., Singh, R.K. and Gill, S.C. (2008). Herbicide resistance in little seed canary grass (Phalaris minor) and its management. In: Proceedings of the $14^{\text {th }}$ Australian Agronomy Conference, Adelaide, South Australia,106p.

Choubey, N.K., Kolhe, S.S. and Tripathi, R.S. (2001). Relative performance of cyhalofop-butyl for weed control in direct-seeded rice. Ind. J. Weed Sci. 33 (3\&4): 132-135.

Chung, I.M., Kim, K.H., Ahn, J.K and Ju, H.J. (1997). Allelopathic potential evaluation of rice cultivars on Echinochloa crus-galli. Korean J. Weed Sci. 17:52-58

Clark, L. J., Aphale, S. L. and Barraclough, P. B. (2000). Screening the ability of rice roots to overcome the mechanical impedance of wax layers: Importance of test conditions and measurement criteria. Plant and 
Soil. 219:187-196.

Datta, D. (1986). Technology development and the spread of direct seeded flooded rice in South-East Asia. Experi. Agri. 22(4): 417-426.

Dawe, D. (2005). Increasing water productivity in ricebased systems in Asia-Past trends, current problems, and future prospects. Plant Prod. Sci. 8(3): 221-230.

Dhillon, B. S., Kataria, P. and Dhillon, P. K. (2010). National food security vis-à-vis sustainability of agriculture in high crop productivity regions. Current Sci. 98:33-36.

Dilday, R.H., Yan, W.G., Moldenhauer, K.A.K. and Gravois, K.A. (1998). Allelopathic activity in rice for controlling major aquatic weeds. In: Olofsdotter M (ed.) Allelopathy in rice. International Rice Research Institute, Manila, pp 7-26.

Dingkuhn, M., Schnie, H. F., De Datta, S. K., Wijangco, E. and Doeffling, K. (1990). Diurnal and developmental changes incanopy gas exchange in relation to growth in transplanted and direct seeded flooded rice. Aust. J. Plant Physio. 17:119- 134.

Farooq, M., Jabran, K., Cheema, Z.A., Wahid, A. and Siddique, K. H. M. (2011). The role of allelopathy in agricultural pest management. Pest Manag. Sci. 67: 493-506.

Farooq, M., Jabran, K., Rehman, H. and Hussain, M. (2008). Allelopathic effects of rice on seedling development in wheat, oat, barley and berseem. Allelo. J. 22: 385-390.

Fofana, B. and Rauber, R. (2000). Weed suppression ability of upland rice under low input conditions in West Africa. Weed Rese. 40:271-280.

Gealy, D.R. and Moldenhauer, K.A. (2012). Use of ${ }^{13} \mathrm{C}$ isotope discrimination analysis to quantify distribution of barnyardgrass and rice roots in a four-year study of weed-suppressive rice. Weed Sci. 60:133-142.

Giri, G.S. (1998). Effect of rice and wheat establishment techniques on wheat grain yield. In Hobbs PR, Bhandri, Raj, ediors. Proceedings of rice-wheat research project workshop, India. pp 65-68.

Gopal, R., Jat, R.K., Malik, R.K., Kumar, V., Alam, M.M., Jat, M.L., Mazid, M.A., Saharawat, Y.S., McDonald, A. and Gupta, R. (2010). Direct Dry Seeded Rice Production Technology and Weed Management in Rice Based Systems. Technical Bulletin. International Maize and Wheat Improvement Center, New Delhi, India, p. 28

Gupta, R. K, Ladha, J. K, Singh, S., Singh, R., Jat, M. L., Saharawat, Y., Singh, V. P., Singh, S. S., Singh, G., Sah, G., Gathala, M. and Sharma, R. K. (2006). Production Technology for Direct Seeded Rice. Technical Bulletin Series 8. In "Rice-Wheat Consortium for the Indo-Gangetic Plains, New Delhi, India," 14pp.

Guzman Garcia, P. and Nieto Illidge, L. (1992). New densities and fertilization to decrease Rhizoctonia solani. Rice. 41, 10-14.

Hamdi, B.A., Inderjit, Olofdotter, M. and Streibig, J.C. (2001). Laboratory bioassay of phytotoxicity. Agron. J. 93:43-48.

Hassan, S.M., Aidy, I.R., Bastawisi, A.O. and Draz, A.E. (1998). Weed management using allelopathic rice varieties in Egypt. In: Olofsdotter M (ed) Allelopathy in rice. International Rice Research Institute, Manila, pp 27-37.

Hira, G. S. and Khera, K. L. (2000). Water resource management in Punjab under rice-wheat production system. Ludhiana, Punjab, India: Department of Soils,
Punjab Agricultural University. Research Bulletin No. 2/2000.

Hobbs, P.R. and Gupta, R.K. (2000). Sustainable resource management in intensively cultivated irrigated ricewheat cropping systems of the Indo-Gangetic Plains of South Asia: Strategies and options. In "International Conference on Managing Natural Resources for Sustainable Production in 21st Century", 14-18 February 2000, New Delhi, India, Pp. 584-592.

Hong, N., Xuan, T., Tsuzuki, E., Terao, H., Matsuo, M. and Khanh, T. (2004). Weed control of four higher plant species in paddy rice fields in Southeast Asia. $J$ Agron. Crop Sci. 190:59-64.

http://a-c-s.cofex.com/crops/2009am/webprogram paper53386.html.

Islam, M. F., Sarkar, M. A. R., Islam, M. S., Parveen, S. and Hossain, M. S. (2008). Effects of crop establishment methods on root and shoot growth, lodging behavior of Aus rice. Inter. J. Biol. Rese. 5:60-64.

Jabran, K. and Farooq, M. (2013). Implications of potential allelopathic crops in agricultural systems. In: Cheema, Z.A., Farooq, M., Wahid, A. (Eds.), Allelopathy, Current Trends and Future Applications. Springer Berlin, Heidelberg, pp. 349-385

Jannink, J. L., Orf, J. H., Jordan, N. R. and Shaw, R. G. (2000). Index selection for weed-suppressive ability in soybean. Crop Sci. 40:1087-1094.

Jat, M.L., Gathala, M.K., Ladha, J.K., Saharawat, Y.S., Jat, A.S., Vipin, K., Sharma, S.K., Kumar, V., and Gupta, R. K. (2009). Evaluation of precision land leveling and double zero-till systems in the rice-wheat rotation: Water use, productivity, profitability and soil physical properties. Soil Till. Rese. 105: 112-121.

Jensen, L.B., Courtois, B., Shen, L., Li, Z., Olofsdotter, M. and Mauleon, R.P. (2001). Locating genes controlling allelopathic effects against barnyardgrass in upland rice. Agron. J. 93:21-26.

Joseph, K., Tomy, P.J. and Nair, N.R. (1990). Relative efficacy of different herbicides for control of weeds in dry seeded low land rice. Oryza. 27(2): 199-201.

Juraimi, A. S., Anwar, M. P., Selamat, A., Puteh, A. and Man, A. 2012. The influence of seed priming on weed suppression in aerobic rice. Pak. J. Weed Sci. Rese. 18: 257-264.

Kabir, M. H., Saha, A., Mollah, I. U., Kabir, M. S. and Rahman, F. (2008). Effect of crop establishment methods and weed management practices on the productivity of boro rice in lowland ecosystem. Inter. J. Bio. Rese. 5:42-51.

Kamboj, B. R, Kumar, A., Bishnoi, D. K., Singla, K., Kumar, V., Jat, M. L., Chaudhary, N., Jat, H. S., Gosain, D. K., Khippal, A., Garg, R., Lathwal, O. P., Goyal, S. P., Goyal, N. K., Yadav, A., Malik, D. S., Mishra, A. and Bhatia, R. (2012). Direct Seeded Rice Technology in Western Indo-Gangetic Plains of India: CSISA Experiences. CSISA, IRRI and CIMMYT $16 \mathrm{pp}$

Kato-Noguchi, H., Salam, M. A. and Suenaga, K. (2011). Isolation and identification of potent allelopathic substances in a traditional Bangladeshi rice cultivar Kartikshail. Plant. Prod. Sci.14(2): 128-134.

Kaur, S. and Singh, S. (2015). Bio-efficacy of different herbicides for weed control in direct-seeded rice. Ind. J. Weed Sci. 47(2):106-109.

Kim, H.H. and Pyon, J.Y. (1998). Weed occurrence and yield loss due to weeds in different direct seeded rice paddy fields. Kor. J. Weed Sci. 18(1): 12-19.

Kumar, V. and Ladha, J. K. (2011). Direct seeding of 
rice: recent developments and future research needs. Advan. Agron. 111: 297-413.

Kumar, V., Ladha, J.K. and Gathala, M.K. (2009). Direct drill-seeded rice: A need of the day. In "Annual Meeting of Agronomy Society of America, Pittsburgh, November 1-5, 2009"

Kumar, V., Singh, S., Chhokar, R.S., Malik, R.K., Brainard, D.C. and Ladha, J.K. (2013). Weed management strategies to reduce herbicide use in zero-till rice-wheat cropping systems of the Indo-Gangetic Plains. Weed Tech. 27: 241-254.

Ladha, J.K., Kumar, V., Alam, M.M., Sharma, S., Gathala, M., Chandra, P., Saharawat, Y.S. and Balasubramanian, V. (2009). Integrating crop and resource management technologies for enhanced productivity, profitability, and sustainability of the ricewheat system in South Asia. in "Integrated Crop and Resource Management in the Rice-Wheat System of South Asia". (J. K. Ladha, Y. Singh, O. Erenstein, and B. Hardy, Eds.), pp. 69-108. International Rice Research Institute, Los Banos, Philippines.

Lee, M.H., Kim, J.K., Kim, S.S. and Park, S.T. (2002). Status of dry-seeding technologies for rice in Korea. In: Pandey et al. (eds.) Direct Seedling: Research and Strategies and Opportunities. Proceedings of the International Workshop on Direct Seeding in Asian Rice Systems: Strategic Research Issues and Opportunities, 25-28 Jan., 2000, Bangkok, Thailand. IRRI. pp. 161-176.

Mahajan, G. and Timsina, J. (2011). Effect of nitrogen rates and weed control methods on weeds abundance and yield of direct-seeded rice. Arch. Agro. Soil Sci. 57(3): 239-250.

Mahajan, G., Chauhan, B.S. and Johnson, D.E. (2009). Weed management in aerobic rice in north western Indo-Gangetic plains. J. Crop Impro. 23(4): 366-382.

Maity, S.K. and Mukherjee, P.K. (2008). Integrated weed management in dry direct-seeded rice (Oryza sativa L.). Ind. J. Agro. 53(2): 116-120.

Malik, M., Singh, R., Singh, G., Singh, R.K. and Yadav, S.K. (2002). Evaluation of dithiopyr for control of weeds in direct-seeded rice. Ind. J. Weed Sci. 34 (3\&4): 287-289.

Matloob, A., Khaliq, A. and Chauhan, B. S. (2015). Weeds of direct-seeded rice in Asia: problems and opportunities. Advan. Agro.130: 291-336.

Mehta, R.K., Singh, G. and Singh, O.P. (1993). Weed management in rainfed lowland rice. Ind. J. Weed Sci. 25(2): 99-101.

Mishra, J.S. and Singh, V.P. (2008). Integrated weed management in dry-seeded irrigated rice (Oryza sativa L.). Ind. J. Agro. 53(4): 299-305.

Mithrasena, Y. J. P. K. and Adikari, W. P. (1986). Effect of density on sheath blight (ShB) incidence. International Rice Research Notes. 11, 20-21.

Mohtisham, A., Ahmad, R., Ahmad, Z. and Aslam, M.R. (2013). Effect of different mulches techniques on weed infestation in aerobic rice (Oryza sativa L.). American-Eurasian Journal of Agriculture and Environmental Science. 13:153-157.

Moody, K. (1983). The status of weed control in Asia. FAO. Plant Protection Bulletin. 30: 119-120.

Moody, K. and Mukhopadhyay, K. (1982). Weed control in dry seeded rice-problems, present status, research direction. In: Rice Research Strategies For The Future. International Rice Research Institute, Manila, Philippines. pp 147-158.
Muthukrishnan, P. and Purushothaman, S. (1992). Effect of irrigation regime, weed control and biofertilizers on growth and yield of rice. Ind. J. Weed Sci. 24(3\&4): 26-29.

Nawaz, A., Farooq, M., Lal, R., Rehman, A., Hussain, T. and Nadeem, A. (2017). Influence of sesbania brown manuring and rice residue mulch on soil health, weeds and system productivity of conservation ricewheat systems. Land Degra. \& Devel. 28:1078-1090.

Naylor, R. (1994). Herbicide use in Asian rice production. World Devel. 22: 55-70.

Olofsdotter, M. (2001). Rice- a step toward to use allelopathy. Agron. J. 93(1): 3-8.

Olofsdotter, M., Jensen, L. and Courtois, B. (2002). Improving crop competitive ability using allelopathy-an example from rice. Plant Breed. 121: 1-9.

Olofsdotter, M., Navarez, D. and Moody, K. (1995). Allelopathic potential in rice (Oryza sativa L.). Ann. Appl. Biol. 127:543-560.

Pandey, S. and Velasco, L. (2002). Economics of directseeding in Asia: Patterns of adoption and research priorities. In, "Rice is life: Scientific Perspective for the $21^{\text {st }}$ Century". Toriyama, K., Heong, K. L., Hardy, B., editors. Los Banos Philippines: International Rice Research Institute, and Tsukuba (Japan): Japan International Rice Research Center for Agricultural Sciences. pp.3-4.

Pantuwan, G., Fukai, S., Cooper, M., Rajatasereekul, S. and O'Toole, J. C. (2002). Yield response of rice (Oryza sativa L.) genotypes to different types of drought under rainfed lowlands. Plant factors contributing to drought resistance. Field Crops Rese. 73:181 $-200$

Perera, K., Ayres, P. and Gunasena, H. (1992). Root growth and the relative importance of root and shoot competition in interactions between rice (Oryza sativa L.) and Echinochloa crus-galli. Weed Rese. 32:67-76.

Qin, J., Hu, F., Li, D., Li, H., Lu, J. and Yu, R. (2010). The effect of mulching, tillage and rotation on yield in non-flooded compared with flooded rice production. $J$. Agro. and Crop Sci. 196:397-406.

Raju, R.A. and Gangwar, B. (2004). Bioefficacy of new promising herbicides on weed management in direct sown puddle rice. Extended summaries vol. 2, International symposium on rice held at Hyderabad (A.P.), India, Oct. 4-6, 2004. pp. 340.

Ranasinghe, L. L. (1995). Enhancement of the weed competitive ability of rice (Oryza sativa L.) cultivars. $\mathrm{Ph}$. D. thesis.

Rao, A.N. and Moody, K. (1994). Ecology and management of weeds in farmers' direct seeded rice (Oryza sativa L.) fields. Consultancy report of work done from $1^{\text {st }}$ July to $31^{\text {st }}$ December, 1994. Los Banos (Philippines): IRRI. pp. 81.

Rao, A.N. and Nagamani, A. (2007). Available technologies and future research challenges for managing weeds in dry-seeded rice in India. In: "Proceeding of the $21^{\text {st }}$ Asian Pacific Weed Society Conference." from 2 to 6 October 2007, Colombo, Sri Lanka, pp. 391491.

Rao, A.N., Johnson, D.E., Shivprasad, B., Ladha, J.K. and Mortimer, A.M. (2007). Weed management in direct-seeded rice. Advan. Agro. 93: 153-255.

Rashid, M.H., Alam, M.M., Khan, M.A.H. and Ladha, J.K. (2009). Productivity and resource use of direct (drum) seeded and transplanted rice in puddle soils in rice-rice and rice-wheat ecosystem. Field Crops Rese. 
113: $274-281$

Saha, S. (2006). Efficacy of herbicides in wet directsown summer rice. Ind. J. Weed Sci. 38(1\&2): 45-48.

Sankula, S., Braverman, M. P. and Linscombe, S. D. (1997). Glufosinate-resistant, BAR- transformed rice (Oryza sativa) and red rice (Oryza sativa) response to glufosinate and in mixtures. Weed Tech. 11, 662666.

Sarma, A. and Gogoi, A. K. (1996). Performance of different weeders in rainfed upland rice (Oryza sativa L.). Ind. J. Weed Sci. 33: 178-182.

Seal, A. and Pratley, J. (2010). The specificity of allelopathy in rice (Oryza sativa). Weed Rese. 50, 303-311.

Seal, A.N., Pratley, J.E., Haig, T., Lewin and L.G. (2004). Screening rice varieties for allelopathic potential against arrowhead (Sagittaria montevidensis), an aquatic weed infesting Australian Riverina rice crops. Crop Pasture Sci. 55:673-680.

Sharma, P.K. and De Datta, S.K. (1985). Effect of puddling on soil physical properties and processes. In "Soil Physics and Rice", pp. 217-234. International Rice Research Institute, Los Banos, Philippines.

Sharma, P.K., Ladha, J.K. and Bhushan, L. (2003). Soil physical effects of puddling in rice-wheat cropping systems. In "Improving the productivity and sustainability of rice-wheat systems: Issues and Impacts" (J. K. Ladha, J. E. Hill, J. M. Duxbury, R. K. Gupta, and R. J. Buresh, Eds.), pp. 97-113. ASA, CSSA, SSSA, Madison, WI, ASA Special Publication 65.

Singh, A., Kaur, R., Kang, J. S. and Singh, G. (2012). Weed dynamics in rice-wheat cropping system. Global J. Bio., Agri. Health Sci. 1(1): 7-16.

Singh, A., Nandal, D. P. and Punia, S. S. (2017). Performance of sequential herbicides to control weeds in direct seeded rice. J. Applied Natural Sci. 9(3):13241328.

Singh, A.K. and Chinnusamy, V. (2006). Aerobic riceProspects for enhancing water productivity. Ind. Farm. 56(7): 58-61.

Singh, B. (1988). Effect of weed control methods on performance of rice varieties under upland rainfed conditions of Nagaland. Ind. J. Weed Sci. 20(2): 5154.

Singh, G., Singh, R.G., Singh, O.P., Kumar, T., Mehta, R.K., Kumar, V. and Singh, R.P. (2005a). Effect of weed-management practices on direct-seeded rice under puddle lowlands. Ind. J. Agron. 50(2): 35-37.

Singh, G., Singh, V.P., Singh, Y., Singh, K.M., Mortimer, M., Johnson, D.E. and White, J. L. (2003). Efficacy of herbicides alone and in combinations in direct seeded rice. Biennial Conference ISWS, March 12-14, G.B. P.U.A.\&T., Pantnagar. pp. 03

Singh, K., Kumar, V., Saharawat, Y. S., Gathala, M. and Ladha, J. K. (2013). Weedy rice: An emerging threat for direct seeded rice production systems in India. $J$. Rice Rese. 1:106.

Singh, R. G., Singh, S., Singh, V. and Gupta, R. K. (2010). Efficacy of azimsulfuron applied alone and tank mixed with metsulfuron+ chlorimuron (Almix) in dry direct seeded rice. Ind. J. Weed Sci. 42(3\&4):168172.

Singh, S., Bhushan, L., Ladha, J. K., Gupta, R. K., Rao, A. N., and Sivaprasad, B. (2006). Weed management in dry-seeded rice (Oryza sativa) cultivated in the furrow-irrigated raised-bed planting system. Crop Prot. 25, 487-495.

Singh, S., Bhushan, L., Ladha, J.K., Gupta, R.K., Rao,
A.N. and Shivprasad, B. (2007). Evaluation of mulching, Inter-cropping with Sesbania and herbicide use for weed management in dry-seeded rice (Oryza sativa L.). Crop Prot. 26: 518-524.

Singh, S., Bhushan, L., Ladha, J.K., Gupta, R.K., Rao, A.N. and Shivprasad, B. (2008). Weed management in aerobic rice systems under varying establishment methods. Crop Prot. 27(3-5): 660-671.

Singh, S., Chhokar, R.S., Gopal, R., Ladha, J.K., Kumar, V. and Singh, M. (2009). Integrated weed management : A key to success for direct-seeded rice in the Indo-Gangetic plains. In :"Integrated Crop and Resource Management in the Rice-Wheat System of South Asia" (J. K. Ladha, Y. Singh, O. Erenstein, and B. Hardy, Eds.), pp. 261-278. International Rice Research institute, Los Banos, Philippines.

Singh, S., Singh, G., Singh, V.P. and Singh, A.P. (2005b). Effect of establishment methods and weed management practices on weeds and rice in ricewheat cropping system. Ind. J. Weed Sci. 37(1\&2): 51 -57 .

Singh, V., Jat, M. L., Ganie, Z. A., Chauhan, B. S. and Gupta, R. K. (2016). Herbicide options for effective weed management in dry direct seeded rice under scented rice-wheat rotation of western Indo Gangetic Plains. Crop Prot. 81:168-176.

Singh, V.P., Singh, G., Singh, S.P., Kumar, A., Singh, Y., Johnson, D.E. and Mortimer, M. (2005c). Effect of rice wheat establishment methods and weed management in irrigated rice-wheat production system. In: Workshop on "Direct seeded rice in the rice-wheat system of the Indo-Gangetic Plains", 1-2 feb. 2005, Pantnagar, Uttaranchal, India, pp. 12.

Singh, Y., Singh, G., Singh, V.P., Singh, R.K., Singh, P., Srivastava, R.S.I. and Saxena, A. (2002). Effect of different establishment methods on rice-wheat and the implication of weed management in Indo-Gangetic Plains. Proceedings of International Workshop on Herbicide resistance management and zero-tillage in rice-wheat system, Hisar, India, March 4-6, 2002. pp. 182186.

Soo, L. K., Subinon, B. J. and Thong, O. S. (1989). Cultural practices and paddy planting in the TrusanSapi Paddy Project Proceeding In-house Seminar on Pad$d y$, Department of Agriculture, Kuala Lumpur, Malaysia.

Tabbal, D.P., Bouman, B.A.M., Bhuiyan, S.L., Sibayan, E.B. and Sattar, M.A. (2002). On-farm strategies for reducing water input in irrigated rice: Case studies in the Philippines. Agri. Water Manag. 56(2): 93-112.

Thakur, T.C. (2006). Rice engineering aspects. Ind. Far. 56(7): 53-57.

Talukder, A., Meisner, C., Baksh, M., Waddington, S. (2006). Wheat-maize-rice cropping on permanent raised beds in Bangladesh. In: Humphreys, E., Roth, C.H. (Eds.), Permanent Beds and Rice Residue Management for Rice-wheat Systems in the Indo-Gangetic plains. ACIAR Workshop Proceedings No. 127, ACIAR, Canberra, Australia, pp. 124-132.

Upasani, R. R. and Barla, S. (2014). Weed control methods in direct seeded rice under medium land condition. J. Crop Weed. 10(2):445-450.

Walia, U.S., Bhullar, M.S., Shelly, N. and Walia, S.S. (2008). Control of complex weed flora of dry-seeded rice (Oryza sativa) with pre- and post-emergence herbicides. Ind. J. Weed Sci. 40, 161-164.

Walia, U.S., Walia, S.S., Amandeep, S.S. and Shelly, N. 
(2012). Bioefficacy of pre-and post-emergence herbicides in direct-seeded rice in Central Punjab. Ind. J.Weed Sci. 44: 3033.

Wells, B. R. and Faw, W. F. (1978). Short-statured rice response to seeding and N rates. Agron. J. 70:477-480.

Wentao, R., Mingjin, X., Jing, L., Chunjiang, B., Yuqiu, S. ahind Ruili, W. (2003). Experimental study on effect of paper-mulching rice planting technology on saving water and controlling weeds. Transactions of the Chinese Society of Agricultural Engineering. 6:014.

Xuan, T. D., Tsuzuki, E., Terao, H., Matsuo, M., Khanh,
T. D., Murayama, S., Hong and N. H. (2003). Alfalfa, rice by-products and their incorporation for weed control in rice. Weed Bio. Manag. 3:137-144.

Yadav, S., Gill, M. S. and Kukal, S. S. (2007). Performance of direct-seeded basmati rice in loamy sand in semi-arid subtropical India. Soil Till. Rese. 97:229238.

Zhao, D., Atlin, G., Bastiaans, L. and Spiertz, J. (2006). Developing selection protocols for weed competitiveness in aerobic rice. Field Crops Rese. 97: 272-285 